\title{
Agnieszka Panasiewicz
}

Uniwersytet Ekonomiczny we Wrocławiu

e-mail: agapanas@o2.pl

\section{ZARZĄDZANIE RYZYKIEM EKOLOGICZNYM JAKO NARZĘDZIE RÓWNOWAŻENIA ROZWOJU ORGANIZACJI}

\begin{abstract}
Streszczenie: Każda działalność człowieka wiąże się z niekorzystnym oddziaływaniem na środowisko. W dzisiejszych czasach konieczne jest jednak prowadzenie działalności w harmonii z przyrodą. Jest to jeden z niezbędnych warunków utrzymania się i dalszego rozwoju przedsiębiorstw na rynku. Dlatego konieczne jest wprowadzenie różnego rodzaju środków, instrumentów, nowych metod zarządzania przedsiębiorstwem, które pozwalają na obniżanie tego wpływu, a tym samym narzędzi pozwalających równoważyć rozwój organizacji. Jednym z narzędzi, którego wdrożenie pozwala na osiągnięcie tego celu, jest zarządzanie ryzykiem ekologicznym. Celem artykułu jest wyjaśnienie pojęcia ryzyka ekologicznego, w różny sposób rozumianego, a także przedstawienie procedury zarządzania nim. Bardzo istotne jest sprecyzowanie kształtu tego procesu, ponieważ jest on bardzo skomplikowany z uwagi na specyfikę ryzyka.
\end{abstract}

Słowa kluczowe: ryzyko ekologiczne, zarządzanie ryzykiem ekologicznym, zrównoważone przedsiębiorstwo.

DOI: $10.15611 /$ pn.2015.377.16

\section{Wstęp}

Każda działalność człowieka wiąże się z niekorzystnym oddziaływaniem na środowisko. Powoduje ona często nieodwracalne szkody w poszczególnych jego komponentach. Szczególnie niebezpieczne dla środowiska są nagłe zagrożenia, jak $\mathrm{np}$. awarie i katastrofy przemysłowe. Równie niebezpieczna jest rabunkowa eksploatacja zasobów środowiska. Negatywne skutki działalności człowieka dla środowiska zaczęły być dostrzegane w latach 60 . minionego wieku. Dyskusja nad tymi problemami doprowadziła $\mathrm{w}$ efekcie do powstania koncepcji zrównoważonego rozwoju (ZR), której powinny przestrzegać przede wszystkim podmioty gospodarcze, ponieważ to one w największym stopniu przyczyniają się do degradacji środowiska naturalnego. Przedsiębiorstwo, które działa zgodnie z zasadami zrównoważonego rozwoju, nazywane jest przedsiębiorstwem zrównoważonym (sustainable enterprises). Jest to przedsiębiorstwo zorientowane na aspekty zarówno ekonomiczne, społeczne, jak i ekologiczne (rys. 1). 


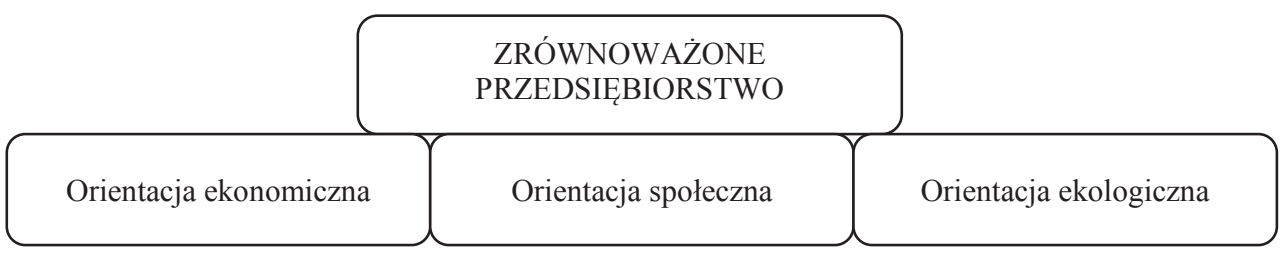

Rys. 1. Zrównoważone przedsiębiorstwo

Źródło: opracowanie własne.

Zrównoważone przedsiębiorstwo, zgodnie z koncepcją ZR, może maksymalizować swój zysk, a jednocześnie ograniczyć swoje niekorzystne oddziaływanie na środowisko. Obecnie prowadzenie działalności w harmonii z przyrodą stanowi jeden z niezbędnych warunków utrzymania się i dalszego rozwoju przedsiębiorstw [Szadziewska 2011]. Dlatego też na całym świecie obserwuje się wzrost znaczenia ochrony środowiska w działalności organizacji. Wprowadzają one różnego rodzaju środki, instrumenty ochrony środowiska, które sprawiają, iż działalność człowieka staje się bardziej przyjazna środowisku. Przedsiębiorstwa muszą odpowiednio zarządzać swoim wpływem na środowisko i starać się zmniejszać to negatywne oddziaływanie. Jest to konieczne nie tylko z uwagi na ochronę środowiska, ale również wynika z tego, iż wszystkie zakłócenia spowodowane zanieczyszczeniem środowiska naturalnego mogą niekorzystnie wpływać na sprawność organizacji, jej ciągłość działania. Jednym z narzędzi pozwalających na obniżenie negatywnego oddziaływania na środowisko jest zarządzanie ryzykiem ekologicznym. W procesie tym ustalany jest rodzaj zagrożenia, skala tego wpływu oraz podejmowane są działania zapobiegawcze lub minimalizujące skutki.

Celem artykułu jest zdefiniowanie ryzyka ekologicznego i przedstawienie procedury zarządzania tym ryzykiem na bazie szerokich studiów literaturowych.

\section{Istota ryzyka ekologicznego}

Każde przedsiębiorstwo funkcjonuje w otoczeniu jako system. Między przedsiębiorstwem a otoczeniem zachodzą wzajemne oddziaływania. Te wzajemne relacje pomiędzy przedsiębiorstwem i jego otoczeniem stwarzają dla obu stron zarówno szanse, jak i zagrożenia.

W obecnych czasach otoczenie, w którym działa przedsiębiorstwo, jest bardzo dynamiczne. Przedsiębiorstwo musi liczyć się z możliwością wystąpienia wielu rodzajów ryzyka. Ryzyko jest nierozerwalnie związane z każdą działalnością prowadzoną przez człowieka. Nawet najmniejsza firma narażona jest na ryzyko. Zgodnie z ISO/IEC 73 ryzyko można zdefiniować jako kombinację prawdopodobieństwa wystąpienia zdarzenia oraz jego skutków [Norma ISO/IEC 73]. 
Jednym z rodzajów ryzyka, na które narażone jest przedsiębiorstwo i jego otoczenie, jest w różny sposób definiowane ryzyko środowiskowe. Większość autorów utożsamia ryzyko środowiskowe z ryzykiem ekologicznym, co wydaje się, zdaniem autorki, niedostatecznie uzasadnione. Zgodnie z definicją EPA ${ }^{1}$ ryzyko środowiskowe oznacza prawdopodobieństwo, że dane zdarzenie lub działanie spowoduje szkody dla zdrowia lub/i środowiska [EPA 1992]. Zdaniem autorki w definicji ryzyka środowiskowego większy nacisk należy położyć na to, iż może ono być powodowane przez dwa rodzaje oddziaływań, a mianowicie:

- oddziaływanie sił przyrody na człowieka i gospodarkę (oddziaływanie antroposferyczne),

- oddziaływanie człowieka, prowadzonej przez niego działalności na środowisko (oddziaływanie biosferyczne).

Dlatego też, w opinii autorki, ryzyko środowiskowe można zdefiniować jako prawdopodobieństwo wystąpienia szkód majątkowych, osobowych w przedsiębiorstwie i jego otoczeniu oraz w środowisku naturalnym, wynikających z wzajemnych oddziaływań przedsiębiorstwa i środowiska. Zgodnie z powyższą definicją ryzyko środowiskowe to ryzyko rodzajowe, na które składają się trzy rodzaje ryzyka, a mianowicie:

- środowiskowe ryzyko zdrowotne - prawdopodobieństwo wystąpienia szkód osobowych wynikających z wzajemnego oddziaływania przedsiębiorstwa i środowiska, jego istotą jest fakt, że zanieczyszczenie będzie miało wpływ na zdrowie ludzkie,

- ryzyko ekologiczne - prawdopodobieństwo wystąpienia szkód w środowisku naturalnym wynikających z wzajemnych oddziaływań przedsiębiorstwa i środowiska, jego istotą jest fakt, iż zanieczyszczenie będzie miało wpływ na środowisko naturalne,

- środowiskowe ryzyko majątkowe - prawdopodobieństwo wystąpienia szkód majątkowych wynikających $\mathrm{z}$ wzajemnego oddziaływania przedsiębiorstwa i środowiska, jego istotą jest fakt, iż zanieczyszczenie będzie miało wpływ na majątek ludzki (por. [Borys, Panasiewicz 2001]).

\section{Procedura zarządzania ryzykiem ekologicznym}

Proces zarządzania ryzykiem ekologicznym jest trudny. Wymaga zastosowania wiedzy z różnych dziedzin naukowych. Zarządzanie ryzykiem ekologicznym można określić jako działania, których celem jest wyeliminowanie lub obniżenie ryzyka ekologicznego do wielkości akceptowanej (por. [Mniszek 2000]).

Na całość procesu zarządzania ryzykiem ekologicznym składają się dwie fazy:

- faza analizy ryzyka, której celem jest zidentyfikowanie i ocenienie ryzyka,

${ }^{1}$ Environmental Protection Agency. 
- faza postępowania z ryzykiem, której celem jest wybór metod sterowania ryzykiem, wdrożenie ich w życie oraz monitorowanie i aktualizacja podjętych rozwiązań.

Analiza ryzyka ekologicznego jest procesem, w którym bada się dwa główne składniki ryzyka, a mianowicie narażenie i skutki oraz relacje zachodzące pomiędzy nimi. W analizie tej stosuje się metody ilościowe i jakościowe w celu scharakteryzowania ryzyka narażenia na określoną substancję zanieczyszczającą. Analiza ryzyka ekologicznego jest znacznie bardziej złożona niż analogiczne czynności dla innych zdarzeń. Jest to proces naukowy bardzo skomplikowany, trudny i interdyscyplinarny. $\mathrm{Z}$ tego też powodu powinni zajmować się nim specjaliści będący przedstawicielami różnych dziedzin naukowych (lekarze, toksykolodzy, ekolodzy, statystycy). Zgodnie z rekomendacją Amerykańskiej Agencji Ochrony Środowiska (US EPA) proces analizy ryzyka powinien składać się z następujących etapów [Biesiada, Bubak 2000]:

- identyfikacji zagrożenia,

- oceny zależności dawka-reakcja,

- oceny narażenia,

- charakterystyki ryzyka.

Identyfikacja ryzyka polega na zbieraniu i ocenie danych na temat zagrożeń. Przede wszystkim należy zebrać informacje dotyczące:

- stanu środowiska przyrodniczego terenu mogącego znaleźć się w obszarze oddziaływania czynników niebezpiecznych emitowanych przez przedsiębiorstwo (określenie istniejących ekosystemów, identyfikacja warunków środowiskowych, które mogą wpływać na wielkość narażenia, czyli klimat, roślinność, rodzaj gleby itp.),

- potencjalnych i istniejących źródeł emisji zanieczyszczeń (określenie czynników szkodliwych dla środowiska, wielkość emisji, możliwości przemian substancji w środowisku i ich przemieszczania się, gdyż zanieczyszczenie, które dostaje się do środowiska, może przemieszczać się do powietrza, gleby, pobliskich rzek i wód gruntowych lub też dostać się do łańcucha pokarmowego) [Borysewicz 2000],

- informacji, czy dany czynnik chemiczny, fizyczny powoduje szkodliwe działanie, a jeśli tak, to jakiego rodzaju szkody powoduje.

W celu zidentyfikowania niebezpieczeństw należy poddać dogłębnej analizie całą organizację. Identyfikacja zaczyna się spisem wszystkich zagrożeń, które mogą spowodować szkody ekologiczne. Ostatecznym celem tego etapu jest stworzenie szczegółowej listy zagrożeń. Istnieje wiele metod identyfikacji i oceny ryzyka ekologicznego w przedsiębiorstwie. Wybór metody zależy od wielu czynników. Przy identyfikacji zagrożeń można skorzystać z pewnych technik, narzędzi identyfikacji, ułatwiających proces identyfikacji. Przedstawia je tab. 1.

Identyfikacja ryzyka jest bardzo ważnym etapem analizy, ponieważ uzyskane wyniki wykorzystywane są w pozostałych etapach i wpływają na dokładność całego procesu. 
Tabela 1. Techniki identyfikacji ryzyka

\begin{tabular}{|c|c|}
\hline $\begin{array}{c}\text { Metoda } \\
\text { badania ryzyka }\end{array}$ & Opis metody \\
\hline $\begin{array}{l}\text { Analiza } \\
\text { dokumentów }\end{array}$ & $\begin{array}{l}\text { Polega na identyfikacji ryzyka ekologicznego na podstawie analizy dokumentów. Jest } \\
\text { to metoda, która dostarcza najwięcej informacji o ryzyku. Przede wszystkim należy } \\
\text { przeanalizować następujące dokumenty: koncesje, licencje, pozwolenia ekologiczne, protokoły } \\
\text { z przeprowadzonych w przedsiębiorstwie kontroli oraz wydane decyzje pokontrolne, akta spraw } \\
\text { o wszczęciu postępowań wobec przedsiębiorstwa za naruszenie wymogów ochrony środowiska, } \\
\text { plany zabezpieczeń na wypadek awarii, sprawozdania audytorów środowiskowych (raporty } \\
\text { z przeglądów w zarządzaniu środowiskiem) oraz audytów certyfikujących. Ważne źródło } \\
\text { informacji stanowi system rachunkowości w przedsiębiorstwie. Analiza tych dokumentów może } \\
\text { dostarczyć osobie zarządzającej ryzykiem ekologicznym wielu informacji na temat istniejących } \\
\text { typów ryzyka i na sformułowanie pierwszych wniosków dotyczących istniejących zagrożeń. }\end{array}$ \\
\hline Inspekcje & $\begin{array}{l}\text { Polega na przeprowadzeniu oględzin urządzeń i procesów w przedsiębiorstwie. Stosując tę } \\
\text { metodę, można również osobiście zapoznać sięz warunkami pracy. Ta metoda może dostarczyć } \\
\text { informacji o tym, czy pracownicy we właściwy sposób obchodzą się np. z materiałami } \\
\text { niebezpiecznymi, czy są one we właściwy sposób składowane. Można również osobiście } \\
\text { sprawdzić, jaki jest stan techniczny urządzeń ochronnych itp. Według niektórych inspekcje } \\
\text { są najlepszą drogą uzyskania informacji o wszelkich zagrożeniach. Jednak należy również } \\
\text { zdawać sobie sprawę, że metoda ta ma wady. Za jej podstawowe mankamenty należy uznać: } \\
\text { czasochłonność, wysokie koszty oraz brak reprezentatywności wyników. }\end{array}$ \\
\hline $\begin{array}{l}\text { Metoda } \\
\text { ankietowa }\end{array}$ & $\begin{array}{l}\text { Metoda ankietowa polega na zastosowaniu odpowiednio przygotowanych kwestionariuszy. } \\
\text { Jest ona metodą, która dostarcza wiele informacji na temat źródeł zagrożeń środowiska i } \\
\text { ryzyka ekologicznego w przedsiębiorstwie. Najlepiej, aby kwestionariusz przygotowywany } \\
\text { był przez osobę, która bardzo dobrze zna podmiot, jego specyfikę. Do zalet tej metody należy } \\
\text { zaliczyć przede wszystkim szybkość przeprowadzenia oceny. Główną wadą jest możliwość } \\
\text { zatajenia ważnych informacji przez ankietowanych. Adresatami takiej ankiety mogą być nie } \\
\text { tylko pracownicy przedsiębiorstwa, ale również osoby i instytucje z jego otoczenia, np. zakłady } \\
\text { ubezpieczeń, administracja samorządowa, organizacje proekologiczne, okoliczni mieszkańcy. }\end{array}$ \\
\hline Metoda HAZOP & $\begin{array}{l}\text { Metoda ta polega na systematycznym badaniu planowanych lub istniejących produktów, procesów, } \\
\text { procedur oraz systemów. Analiza przy wykorzystaniu tej metody ma na celu identyfikację } \\
\text { potencjalnych zagrożeń (awarii) i innych strat spowodowanych odchyleniami od założonych } \\
\text { warunków operacyjnych systemu. Narzędzie to zaliczane jest do analiz jakościowych. }\end{array}$ \\
\hline $\begin{array}{l}\text { Metoda } \\
\text { macierzowa }\end{array}$ & $\begin{array}{l}\text { W celu stworzenia podstaw do pomiaru i oceny ryzyka ekologicznego przedsiębiorstw można } \\
\text { posłużyć się trzema macierzami: } \\
\text { 1) do oceny ryzyka mającego swoje źródło w działalności przedsiębiorstwa, macierz ta ujmuje } \\
\text { wszystkie obszary, które mogą generować ryzyko ekologiczne, oraz wszystkie kryteria oceny } \\
\text { ryzyka; } \\
\text { 2) do oceny ryzyka związanego z produktami tego przedsiębiorstwa, ujmuje ona wszystkie fazy } \\
\text { jego życia oraz stopień uciążliwości ekologicznej; } \\
\text { 3) do oceny ryzyka spowodowanego nadzwyczajną sytuacją w środowisku przyrodniczym } \\
\text { otaczającym przedsiębiorstwo, powinna ona ujmować opis elementów środowiska (otoczenia) } \\
\text { mogących spowodować zagrożenie dla przedsiębiorstwa oraz kryteria oceny [Metody oceny } \\
\text { ryzyka ekologicznego...]. }\end{array}$ \\
\hline $\begin{array}{l}\text { Metoda drzew } \\
\text { zdarzeń (FTA - } \\
\text { analiza drzewa } \\
\text { niezdatności, } \\
\text { ETA - analiza } \\
\text { drzewa zdarzeń, } \\
\text { HRA - analiza } \\
\text { niezawodności } \\
\text { człowieka) }\end{array}$ & $\begin{array}{l}\text { Metoda ta polega na opracowywaniu graficznych modeli zależności przyczynowo-skutkowych } \\
\text { występujących w rozpatrywanym problemie. Celem zastosowania takich modeli logicznych } \\
\text { jest identyfikacja związków pomiędzy przyczynami a kombinacją zdarzeń, które mogą } \\
\text { powodować zagrożenie. }\end{array}$ \\
\hline
\end{tabular}

Źródło: opracowanie własne na podstawie [Metody oceny ryzyka ekologicznego...]. 
Drugim etapem analizy ryzyka ekologicznego jest ocena zależności dawka (stężenie)-reakcja (skutki). Głównym celem tego etapu jest określenie związku pomiędzy poziomem narażenia a zasięgiem i rozmiarem skutków, jakie powoduje dane zagrożenie. Na tym etapie określa się stężenie substancji, poniżej którego nie powoduje ona wystąpienia szkodliwych skutków w środowisku naturalnym. Stężenie takie oznacza się jako PNEC i określa się je jako przewidywane stężenie niewywołujące skutków w środowisku. Wartość PNEC oblicza się poprzez wprowadzenie odpowiedniego współczynnika szacowania do wyników badań przeprowadzonych na organizmach żywych. Przykładem takiego współczynnika są następujące wskaźniki toksyczności [Biesiada, Bubak 2000]:

- medialna dawka śmiertelna, oznaczana jako $\mathrm{DL}_{50}$ - jest to uzyskana statystycznie w badaniach na zwierzętach pojedyncza dawka związku, która może powodować śmierć 50\% narażonych zwierząt,

- medialne stężenie śmiertelne $\mathrm{CL}_{50}$, które jest uzyskanym w analizie statystycznej stężeniem związku, które może spowodować w czasie narażenia lub w ustalonym czasie po narażeniu śmierć 50\% narażonych organizmów w populacji.

Trzecim etapem procesu analizy ryzyka jest ocena narażenia. Narażenie można zdefiniować jako proces, w wyniku którego dochodzi do kontaktu organizmu i środowiska z substancją zanieczyszczającą [Biesiada, Bubak 2000]. Ocena narażenia obejmuje określenie jakościowe i ilościowe wielkości, częstości, czasu trwania, drogi narażenia oraz receptora narażonego na zagrożenia. Jest to ocena ilościowa i jakościowa, która powinna dawać odpowiedzi na następujące pytania:

- jaki element środowiska jest narażony na zanieczyszczenia,

- przez jaki okres czasu jest on narażony,

- jak często jest on narażony.

Celem szacowania narażenia dla środowiska naturalnego jest określenie stężenia substancji, które występują lub mogą wystąpić w środowisku naturalnym. Stężenie to określa się jako przewidywalne stężenie w środowisku i oznacza jako PEC.

Ostatnim, końcowym etapem analizy ryzyka jest jego charakterystyka. To etap, który jest podstawą do podjęcia dalszych działań w procesie zarządzania ryzykiem ekologicznym. Charakterystyka ryzyka polega na zestawieniu wszystkich uzyskanych wcześniej danych na temat ryzyka i na ich podstawie dokonuje się ilościowej oceny ryzyka i oceny niepewności [Kulka, Rzychoń 2004]. W tym celu obliczone dawki substancji pobranych porównuje się z określonymi miarami. Polega to na porównaniu wskaźnika PEC ze wskaźnikiem PNEC. Celem tego porównania jest ustalenie wartości stosunku PEC/PNEC. Jeżeli stosunek ten będzie mniejszy od jedności bądź równy jedności, nie są potrzebne dalsze badania lub dodatkowe informacje na ten temat, a dotychczas podejmowane działania ograniczające ryzyka są wystarczające. Gdy wartość tego stosunku jest większa od jedności, bada się, czy potrzebne są dodatkowe informacje i badania oraz czy należy rozpocząć działania mające na celu redukcję, ograniczenie ryzyka. 
Drugą fazą procesu zarządzania ryzykiem ekologicznym jest faza postępowania z ryzykiem. W fazie tej należy wybrać, a następnie wdrożyć metody sterowania ryzykiem oraz dokonywać na bieżąco oceny i aktualizacji podjętych rozwiązań. Etapy drugiej fazy procesu zarządzania ryzykiem ekologicznym przedstawia rys. 2.

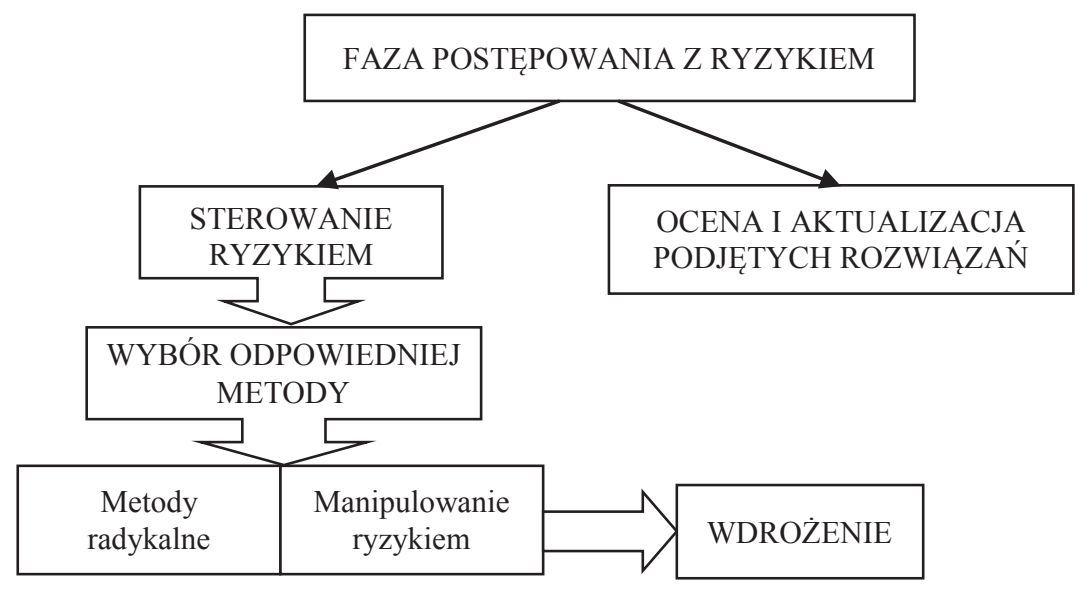

Rys. 2. Faza postępowania z ryzykiem

Źródło: opracowanie własne.

Pierwszym etapem tej fazy jest sterowanie ryzykiem. Na tym etapie należy wybrać odpowiednią metodę kontroli ryzyka, a następnie ją wdrożyć. Metody, które zostaną wybrane przez organizację, muszą spełniać pewne warunki. Przede wszystkim muszą być efektywne kosztowo, czyli koszt ich wdrożenia i zastosowania nie może przewyższać kosztów, jakie niesie za sobą realizacja ryzyka. Ponadto nie mogą one zakłócać funkcjonowania organizacji, czyli muszą pozwalać na utrzymanie wysokiej sprawności operacyjnej. Wybrane metody przedstawione zostały w tab. 2 .

Tabela 2. Metody kontroli ryzyka

\begin{tabular}{|c|l|l|}
\hline \multicolumn{2}{|c|}{ Metody kontroli ryzyka } \\
\hline Grupa metod & Nazwa metody & \multicolumn{1}{|c|}{ Opis } \\
\hline 1 & 2 & \multicolumn{1}{|c|}{3} \\
\hline $\begin{array}{l}\text { Metody } \\
\text { radykalne }\end{array}$ & $\begin{array}{l}\text { Unikanie } \\
\text { ryzyka }\end{array}$ & $\begin{array}{l}\text { Zaliczana do negatywnych metod. Polega na eliminowaniu } \\
\text { zagrożeń poprzez usuwanie ich przyczyn. Najczęściej wiąże się } \\
\text { z podjęciem takich działań, które doprowadzą do całkowitego } \\
\text { wyeliminowania istniejących zagrożeń. }\end{array}$ \\
\cline { 2 - 3 } & $\begin{array}{l}\text { Zatrzymanie } \\
\text { ryzyka }\end{array}$ & $\begin{array}{l}\text { Podjęcie decyzji o samodzielnym jego finansowaniu. Działanie } \\
\text { to może być podjęte celowo lub wynikać z pomyłki. Ryzyko } \\
\text { ekologiczne jest ryzykiem, które niesie za sobą konieczność } \\
\text { pokrycia dużych kosztów, stąd też podmioty bardzo rzadko } \\
\text { powinny korzystać z tej formy sterowania ryzykiem. }\end{array}$ \\
\hline
\end{tabular}




\begin{tabular}{|l|l|l|}
\hline \multicolumn{1}{|c|}{1} & \multicolumn{1}{|c|}{2} & \multicolumn{1}{c|}{3} \\
\hline $\begin{array}{l}\text { Metody } \\
\text { manipulacji } \\
\text { ryzykiem }\end{array}$ & $\begin{array}{l}\text { Zmniejszanie } \\
\text { ryzyka }\end{array}$ & $\begin{array}{l}\text { To podjęcie takich działań, które pozwolą na ograniczenie jego } \\
\text { rozmiarów lub strat, jakie powoduje. Dzięki zastosowaniu } \\
\text { prostych i tanich środków można doprowadzić do zmniejszenia } \\
\text { prawdopodobieństwa wystąpienia zagrożenia lub zmniejszyć jego } \\
\text { rozmiary. W celu zmniejszenia ryzyka można np. wprowadzać } \\
\text { procedury bezpieczeństwa, zastosować różnego rodzaju systemy } \\
\text { wczesnego ostrzegania, zastosować urządzenia, które pozwolą } \\
\text { na zmniejszenie emisji zanieczyszczeń, rozwiązania } \\
\text { technologiczne o odpowiednich standardach. }\end{array}$ \\
\cline { 2 - 4 } & $\begin{array}{l}\text { Ograniczanie } \\
\text { i zmniejszanie } \\
\text { strat }\end{array}$ & $\begin{array}{l}\text { Z tego narzędzia korzysta się wówczas, gdy pomimo podjęcia } \\
\text { poprzednich działań wystąpiły zdarzenia powodujące określone } \\
\text { szkody. W takim przypadku należy podjąc działania, które } \\
\text { pozwolą na ograniczenie rozmiarów szkody. W tym celu każdy } \\
\text { podmiot prowadzący działalność powinien mieć opracowany } \\
\text { plan postępowania w sytuacjach alarmowych w celu podjęcia } \\
\text { w odpowiednim czasie działań, które pozwolą na ograniczenie } \\
\text { powstałej szkody. }\end{array}$ \\
\cline { 2 - 4 } & $\begin{array}{l}\text { Przeniesienie } \\
\text { i finansowanie } \\
\text { ryzyka }\end{array}$ & $\begin{array}{l}\text { Może ono występować w dwóch formach, a mianowicie: } \\
- \text { umowne przeniesienie ryzyka na inny (lub inne) podmiot, } \\
- \text { przeniesienie ryzyka na firmę ubezpieczeniową poprzez zawarcie } \\
\text { umowy ubezpieczenia na wypadek ryzyka uszkodzenia środowi- } \\
\text { ska; ubezpieczenia takie określa się mianem ubezpieczeń ekolo- } \\
\text { gicznych. }\end{array}$ \\
\hline
\end{tabular}

Źródło: opracowanie własne.

Drugim etapem tej fazy jest ocena i aktualizacja podjętych rozwiązań. Na tym etapie należy na bieżąco kontrolować, jakie efekty przynosi wdrożona metoda sterowania ryzykiem. Należy również kontrolować, czy nie pojawiają się nowe, wcześniej niezidentyfikowane typy ryzyka.

Zarządzanie ryzykiem ekologicznym powinno być wdrożone w każdej organizacji. Jak wykazują badania przeprowadzane wśród przedsiębiorstw europejskich, są one coraz bardziej świadome zagrożeń wynikających z zanieczyszczenia środowiska i zdają sobie sprawę z konieczności szybkiego rozpoznawania i podejmowania działań zmniejszających ryzyko ekologiczne. W 2013 roku firma ubezpieczeniowa AIG wraz serwisem Strategic Risk Europe przeprowadziła badanie ankietowe ${ }^{2}$ dotyczące postrzegania typów ryzyka środowiskowego. $Z$ badania tego wynika, iż respondenci za największe zagrożenia środowiskowe uważają: katastrofy naturalne, wycieki substancji toksycznych, emisje zanieczyszczeń do atmosfery, a także zmiany w obszarze prawa środowiskowego czy zmiany klimatu. Co jest bardzo istotne, $75 \%$ badanych przedsiębiorstw dostrzegło ryzyko negatywnego wpływu incyden-

${ }^{2}$ Ankieta została przeprowadzona wśród 37 firm europejskich reprezentujących różne sektory i branże, w tym produkcyjną, spedycyjną, transportową (lotnictwo), a także usługi finansowe, konsultingowe, handel detaliczny oraz jednostki samorządowe. 
tów środowiskowych na reputację firmy. Przeprowadzona ankieta pokazała, że w przypadku 49\% firm budujących politykę odpowiedzialności społecznej biznesu (CSR) zarządzanie ryzykiem środowiskowym jest sprawą pierwszorzędną. Paradoksalnie jednak aż 67\% firm nie posiada wewnętrznych planów zarządzania sytuacją kryzysową w przypadku wystąpienia zagrożeń środowiskowych [„Gazeta Ubezpieczeniowa" 2013].

\section{Zakończenie}

Aktualnie niezbędnym warunkiem rozwoju przedsiębiorstwa jest prowadzenie działalności z poszanowaniem środowiska naturalnego. Na całym świecie obserwuje się wzrost świadomości ekologicznej. Przedsiębiorstwa, które chcą utrzymać odpowiednią pozycję na rynku i w dalszym ciągu się rozwijać, muszą w odpowiedni sposób podchodzić do problemów związanych z ochroną środowiska. Każda, nawet najmniejsza firma musi zdawać sobie sprawę z tego, iż jej działalność wiąże się z negatywnym wpływem na środowisko. Dlatego przedsiębiorstwa muszą zarządzać swoim wpływem na środowisko. W tym celu, posługując się odpowiednimi narzędziami, muszą ustalać, jaki jest rodzaj i skala tego wpływu, oraz podejmować kroki minimalizujące to oddziaływanie. Jednym z narzędzi, które umożliwia tego rodzaju działania, jest zarządzanie ryzykiem ekologicznym. Jest to proces, który z uwagi na stale rosnącą odpowiedzialność przedsiębiorstw za szkody środowiskowe powinien stanowić centralny punkt zarządzania organizacją. Odpowiednio przeprowadzane pozwala $\mathrm{w}$ odpowiednim momencie zidentyfikować ryzyko ekologiczne i podjąć działania minimalizujące prawdopodobieństwo realizacji tego ryzyka oraz minimalizujące skutki, jakie za sobą niesie. Tym samym wdrożenie tego procesu pozwala na zmniejszanie oddziaływania przedsiębiorstwa na środowisko. Jednak, aby zarządzanie ryzykiem ekologicznym przynosiło pożądane efekty, proces ten musi być w odpowiedni sposób wdrożony i przeprowadzany w przedsiębiorstwie. Stąd też ważne są dalsze badania nad jego kształtem i sposobem przeprowadzania w organizacji.

\section{Literatura}

Biesiada M., Bubak A., Podstawy oceny środowiskowego ryzyka zdrowotnego, [w:] Ocena środowiskowego ryzyka zdrowotnego, zarzadzanie i nadzór nad ryzykiem oraz komunikacja o ryzyku - materiały szkoleniowe, Instytut Medycyny Pracy i Zdrowia Środowiskowego, Sosnowiec, 11-12 grudnia 2000.

Borys T., Panasiewicz A., Metodyka zarządzania ryzkiem środowiskowym, „Taksonomia” nr 9, Wydawnictwo AE we Wrocławiu, Wrocław.

Borysiewicz M., Kryteria akceptowalności ryzyka poważnych awarii przemysłowych, Warszawa 2002, s. 8, http://manhaz.cyf.gov.pl/manhaz/Awarie_przemyslowe/ryzyko.html.

EPA: Risk Assessment, EPA/600/M-91/034, United States Environmental Protection Agency, Washington 1992. 
Ergo Hestia, Ekoszkody - krótki przewodnik po ryzyku, http://www.ergohestia.pl/_items/pdf/eko_szkody_krotki_przewodnik_po_ryzyku.pdf (10.10.2013).

„Gazeta Ubezpieczeniowa”, 4 września 2013, http://www.gu.com.pl/index.php?option=com_content\& view=article \&id=48674:aig-i-sre-ryzyka-i-ubezpieczenia-rodowiskowe-wg-firm-w-europie\&cati $\mathrm{d}=53$ : wiat\&Itemid=107 (18.05.2014).

Kulka E., Rzychoń D., Podstawy oceny ryzyka zdrowotnego spowodowanego zanieczyszczeniem środowiska, [w:] R. Janikowski, Środowisko a zdrowie. Polityka. Zarządzanie. Komunikowanie, Wydawnictwo Ekonomia i Środowisko, Białystok 2004.

Metody oceny ryzyka ekologicznego w bieżacej działalności przedsiębiorstwa, http://www.proekologia. pl/e107_plugins/content/content.php?content.42452.2 (15.03.2014).

Mniszek W., Narażenie na substancje chemiczne w kontekście zarządzania i nadzoru nad ryzykiem, [w:] Ocena środowiskowego ryzyka zdrowotnego, zarzadzanie i nadzór nad ryzykiem oraz komunikacja o ryzyku - materiaty szkoleniowe, Instytut Medycyny Pracy i Zdrowia Środowiskowego, Sosnowiec, 11-12 grudnia 2000, s. 30.

Norma ISO/IEC 73.

Szadziewska A., Instrumenty ekonomiczne ochrony środowiska i ich wplyw na wynik finansowy przedsiębiorstwa, http://zif.wzr.pl/pim/2011_1_1_35.pdf(17.10.2013).

\section{ENVIRONMENTAL RISK MANAGEMENT IN THE PROCESS OF SUSTAINABLE DEVELOPMENT}

Summary: Every human activity is associated with adverse effects on the environment. To prevent this it is necessary to introduce different types of resources, tools and new methods of business management. One of the tools, the implementation of which allows to achieve this goal, is to manage environmental risk. This article presents the environmental risk management procedures.

Keywords: ecological risk, ecological risk management, sustainable enterprise. 